\author{
Tomasz Rachwal \\ Uniwersytet Pedagogiczny \\ im. Komisji Edukacji Narodowej \\ w Krakowie
}

\title{
10 lat konferencji z cyklu „Przedsiębiorczość - Edukacja” organizowanych przez Zakład Przedsiębiorczości i Gospodarki Przestrzennej Instytutu Geografii Uniwersytetu Pedagogicznego w Krakowie
}

\author{
10 years of the conferences on "Entrepreneurship - Education" organized \\ by the Department of Entrepreneurship and Spatial Management of Institute \\ of Geography, Pedagogical University of Cracow
}

W 2013 r. obchodzony był jubileusz 10-lecia konferencji z cyklu „Przedsiębiorczość - Edukacja”, organizowanych corocznie na początku jesieni w Krakowie przez Zakład Przedsiębiorczości i Gospodarki Przestrzennej Instytutu Geografii Uniwersytetu Pedagogicznego w Krakowie przy współudziale różnych instytucji, pod kierownictwem naukowym prof. Zbigniewa Zioło i dra Tomasza Rachwała. Cele naukowe i praktyczne dla oświaty, a także problematyka konferencji zostały omówione przez prof. Zbigniewa Zioło w artykule otwierającym niniejszy tom czasopisma. Zamieszczona niżej notka ma na celu przedstawienie ważniejszych faktów i danych statystycznych dotyczących organizacji cyklu.

Pomysł na organizację konferencji poświęconych przedsiębiorczości, ze szczególnym uwzględnieniem problematyki edukacji w zakresie przedsiębiorczości, zrodził się w Zakładzie Przedsiębiorczości i Gospodarki Przestrzennej na początku XXI w. w związku z wprowadzeniem od 2002 r. przedmiotu podstawy przedsiębiorczości do szkół ponadgimnazjalnych w ramach kształcenia ogólnego, a więc dotyczącego wszystkich uczniów. W Zakładzie w tym czasie opracowano program nauczania, podręcznik, zeszyt ćwiczeń oraz poradnik dla nauczycieli tego nowego podmiotu (autorstwa Zbigniewa Makieły i Tomasza Rachwała), przygotowano program specjalności nauczycielskiej z zakresu przedsiębiorczości na kierunku geografia, a także program studiów podyplomowych kwalifikacyjnych: przedsiębiorczość, przygotowujących nauczycieli tego przedmiotu. W późniejszym czasie Tomasz Rachwał opracował także słownik szkolny podstaw przedsiębiorczości, a z udziałem pracowników Zakładu - Moniki Borowiec, Wioletty Kilar - scenariusze zajęć edukacyjnych do tego przedmiotu. Od początku zamiarem pomysłodawców i kierowników naukowych konferencji była więc chęć integracji ośrodków naukowych zajmujących się w swojej pracy badawczej przedsiębiorczością ze środowiskiem szkolnym oraz praktykami życia gospodarczego. Miało to swój wyraz zarówno w strukturze uczestników konferencji, w której dużą grupę stanowią nauczyciele, dyrektorzy szkół i doradcy metodyczni, jak i w zaangażowaniu różnych instytucji oraz firm wspierających organizację cyklu. 
Pierwsza konferencja ${ }^{1}$, która odbyła się 28-29 września 2004 r. pod patronatem honorowym Prezydenta Miasta Krakowa prof. Jacka Majchrowskiego, doktora honoris causa Uniwersytetu Pedagogicznego w Krakowie, organizowana była wspólnie z Krajowym Centrum Edukacji Nauczycieli w Warszawie przy udziale patrona strategicznego - wydawnictwa Nowa Era; wydawnictwo to, jedno z czołowych wydawnictw edukacyjnych w Polsce, od początku wspiera organizację cyklu konferencji, obecnie w charakterze współorganizatora. W kolejnych latach rolę współorganizatorów, partnerów lub patronów strategicznych, oprócz wydawnictwa Nowa Era, przyjmowały różne instytucje publiczne i prywatne, w tym:

- Agencja Interaktywna Opcom.pl,

- Fundacja „Edukacja dla Społeczeństwa”,

- Fundacja Edukacji Rynku Kapitałowego,

- Komisja Nadzoru Finansowego,

- Komisja Geografii Przemysłu Polskiego Towarzystwa Geograficznego,

- Krajowe Forum Przedsiębiorczości w Krakowie,

- Narodowy Bank Polski - NBPortal.pl,

- Stowarzyszenie Nauczycieli Przedsiębiorczości i Edukacji Ekonomicznej,

- Studenckie Koło Naukowe Geografów Uniwersytetu Pedagogicznego w Krakowie.

Ze względu na duże zainteresowanie konferencjami uczestników reprezentujących sektor oświatowy oraz potrzebę integracji środowiska nauczycieli przedsiębiorczości od 2008 r. w połączeniu z konferencją organizowane są ogólnopolskie zjazdy nauczycieli przedsiębiorczości. Sesje konferencyjno-zjazdowe w drugim dniu poświęcone są więc w całości problematyce edukacji w zakresie przedsiębiorczości. Oprócz tego organizowane są dyskusje specjalne dotyczące współczesnych problemów edukacji w zakresie przedsiębiorczości oraz warsztaty metodyczne, których tematyka zależy od zapotrzebowania zgłaszanego przez nauczycieli.

Ryc. 1. Liczba zarejestrowanych uczestników konferencji w latach 2004-2013

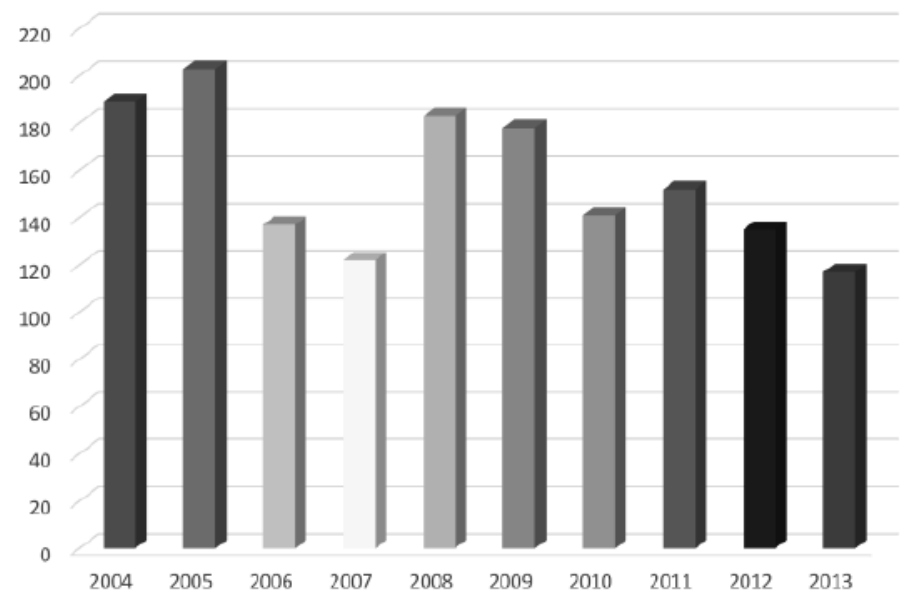

Źródło: opracowanie własne na podstawie list zarejestrowanych uczestników konferencji.

${ }^{1}$ Pełny wykaz organizowanych konferencji znajduje się na końcu artykułu. 
Konferencje cieszą się dużym zainteresowaniem. Każdego roku uczestniczy w nich średnio 150 osób (jako zarejestrowanych uczestników) oraz ok. 200 studentów i doktorantów. Łącznie w latach 2004-2013 zgłosiło się na konferencje i zjazdy ponad 1550 osób (ryc. 1), z czego część stanowili stali uczestnicy przyjeżdżający corocznie do Krakowa.

Wśród uczestników konferencji dominują osoby z Polski, co wynika z faktu, że do $2010 \mathrm{r}$. konferencja miała charakter ogólnokrajowy. Od 2011 r. następuje proces jej umiędzynarodowienia, co zaowocowało obecnością uczestników z Czech, Belgii, Niemiec, Słowacji i Ukrainy. Analiza siedzib instytucji, które reprezentują uczestnicy, lub miejsc zamieszkania uczestników (w przypadku gdy uczestniczą w konferencji prywatnie) wskazuje na to, że pochodzą oni z całej Polski, nawet z odległych północno-wschodnich i północno-zachodnich jej zakątków (ryc. 2). W strukturze przyjezdnych dominują uczestnicy z Krakowa i innych dużych miast Polski (Łodzi, Poznania, Warszawy, Wrocławia) oraz konurbacji górnośląskiej, ale nie brakuje też osób z małych miejscowości, w których działają prężne placówki oświatowe z zaangażowanymi w swoją pracę nauczycielami przedsiębiorczości.

Ryc. 2. Miejsce pochodzenia* uczestników konferencji z Polski w latach 2004-2013

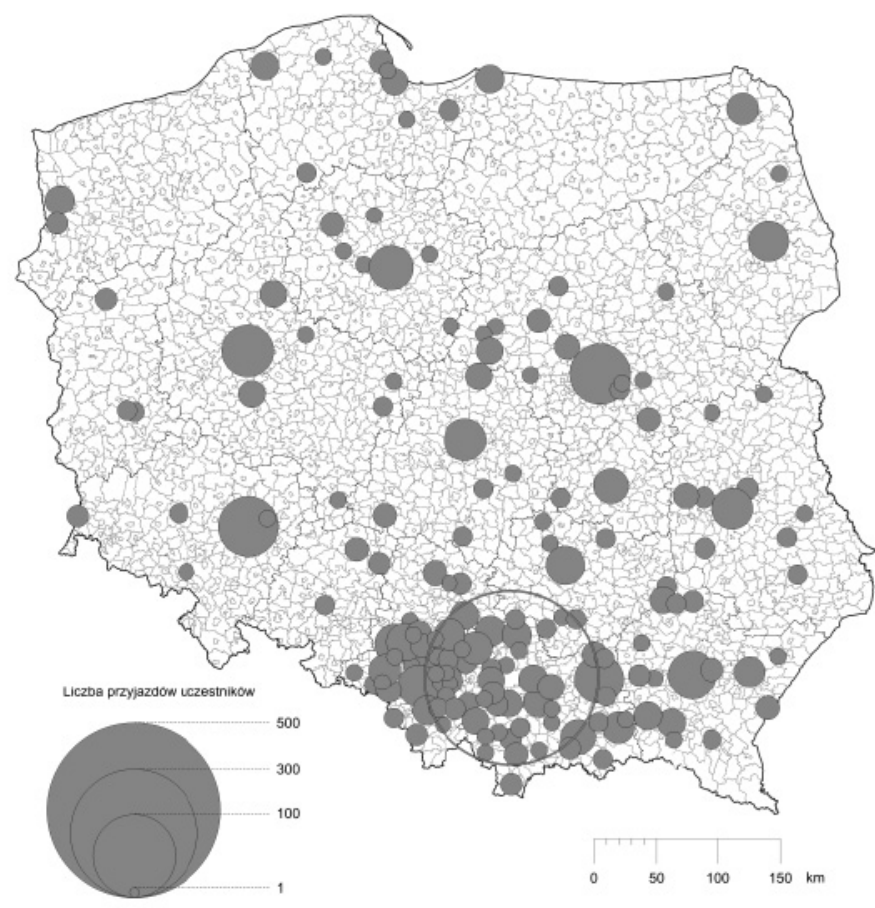

* Miejsce pochodzenia oznacza gminy, w których znajdują się siedziba instytucji reprezentowanej przez danego
uczestnika konferencji lub miejsce jego zamieszkania, w przypadku uczestniczenia w konferencji prywatnie.

Źródło: opracowanie własne na podstawie list zarejestrowanych uczestników konferencji.

Znaczna część uczestników konferencji przygotowuje referaty; w ciągu 10 lat konferencji zgłoszono ich łącznie 413 (ryc. 3). Liczba wystąpień w poszczególnych latach wahała się od 25 do 54 . 
Ryc. 3. Liczba zgłoszonych na konferencje referatów w latach 2004-2013

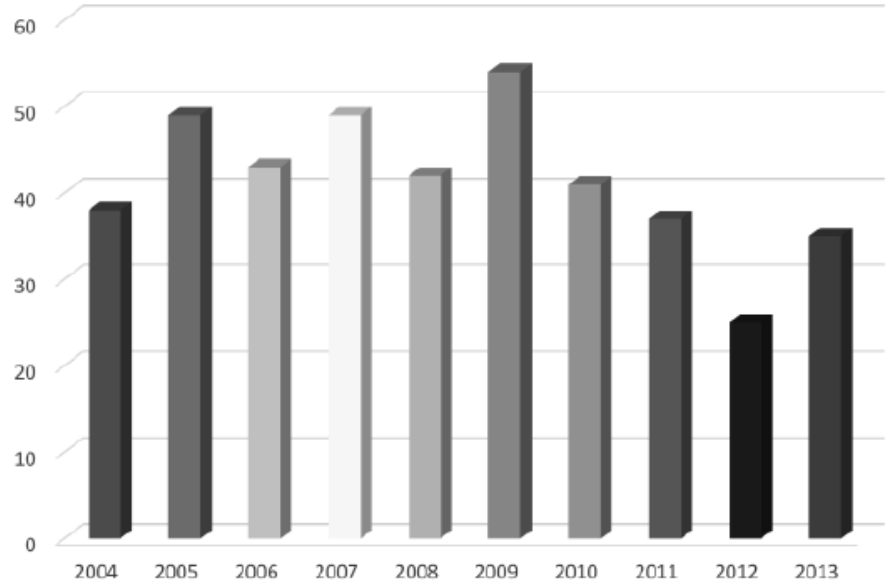

Źródło: opracowanie własne na podstawie programów konferencji.

Efekty obrad konferencji mają swój trwały ślad w postaci artykułów opracowanych na podstawie wygłaszanych referatów, z uwzględnieniem wniosków wynikających z dyskusji, publikowanych w wydawanej od 2005 r. serii wydawniczej, a obecnie - czasopiśmie naukowym „Przedsiębiorczość - Edukacja”. Czasopismo to wpisało się już na stałe w forum dyskusji na tematy związane z rolą przedsiębiorczości w rozwoju układów przestrzennych różnej skali (lokalnych, regionalnych, krajowych), a przede wszystkim na tematy dotyczące aktualnych problemów edukacji w zakresie przedsiębiorczości. Są w nim publikowane artykuły istotne z punktu widzenia praktyki szkolnej, m.in. propozycje zmian w zakresie podstawy programowej przedsiębiorczości, doboru celów, treści i metod kształcenia czy wreszcie ciekawe propozycje realizacji zajęć w szkole. Wszystkie artykuły, zarówno z numeru bieżącego, jak i z numerów archiwalnych, są dostępne bezpłatnie w systemie otwartego dostępu na stronie internetowej czasopisma (http://p-e.up.krakow.pl/) dla wszystkich zainteresowanych. Nowoczesny układ strony pozwala na korzystanie z wielu ciekawych funkcjonalności, m.in. funkcji wyszukiwawczych, generowania notek bibliograficznych itp. w wersji dwujęzycznej (polskiej i angielskiej). Dzięki rejestracji autorzy i czytelnicy mogą otrzymywać aktualne informacje od redakcji, m.in. zapowiedzi nowych numerów. Czasopismo ukazuje się także w wersji tradycyjnej (drukowanej), dzięki czemu jest dostępne również w bibliotekach. Z punktu widzenia naukowego warto zauważyć, że jest ono notowane na liście B Ministerstwa Nauki i Szkolnictwa Wyższego (z liczbą 6 punktów w roku 2013 i 2014) oraz jest uwzględnione w ważnych bazach indeksacji czasopism, m.in. BazEkon, CEJSH czy IndexCopernicus.

Będziemy wdzięczni za wszelkie sugestie dotyczące organizacji konferencji i zjazdów nauczycieli przedsiębiorczości oraz wydawanego czasopisma „Przedsiębiorczość - Edukacja”. Prosimy o przesyłanie ich pocztą tradycyjną na adres sekretariatu konferencji i redakcji lub drogą elektroniczną (przedsiebiorczosc@up.krakow.pl - konferencja i zjazd,pe@up.krakow.pl - czasopismo). Zapraszamy też do publikowania artykułów w czasopiśmie oraz do uczestniczenia w kolejnych konferencjach i zjazdach. Szczegółowe informacje o minionych i przyszłych spotkaniach są dostępne na stronie internetowej cyklu: www.przedsiebiorczosc.eu lub http://www.up.krakow.pl/geo/przedsiebiorczosc.html. 